\title{
ANALISIS KESALAHAN PELAFALAN HURUF KONSONAN TSU DALAM BAHASA JEPANG TERHADAP PENUTUR BAHASA INDONESIA
}

\author{
Rahmawati Eka Pratiwi, Ahmad Dahidi', Nuria Haristiani ${ }^{2}$ \\ Departemen Pendidikan Bahasa Jepang, Fakultas Pendidikan Bahasa dan Sastra, Universitas \\ Pendidikan Indonesia \\ takagiama@ymail.com
}

\begin{abstract}
Abstrak
Pada saat mempelajari bahasa asing, pada umumnya kita tentu akan mempelajariya huruf dari bahasa tersebut. Setiap bahasa memiliki fonem yang berbeda-beda. Pembelajaran huruf dan bagaimana cara melafalkannya merupakan pembelajaran dasar dalam pembelajaran bahasa asing. Fonem adalah bunyi terkecil yang dapat membedakan makna, sedangkan huruf adalah lambang bunyi atau lambang fonem. Misalnya, dalam bahasa Indonesia yang membedakan kata "kelas" dan "keras" adalah fonem /1/ dan /r/. Contoh lainnya yang berhubungan dengan bahasa Jepang. Pada penulisan bahasa Jepang, sering kita temukan kata dari bahasa asing yang ditulis dengan fonem yang sama. Misalnya, kata "light" (cahaya) dan "right" (kanan) yang memiliki makna yang berbeda, namun sama-sama ditulis dengan huruf atau lambang fonem yang sama yaitu「ライト」/raito/. Dengan kesalahan seperti ini akan mudah sekali terjadi kesalahpahaman dalam berkomunikasi. Terutama, komunikasi verbal.Setelah membandingkan fonem yang dimiliki oleh bahasa Jepang dan bahasa Indonesia, salah satu fonem bahasa Jepang yang tidak terdapat dalam bahasa Indonesia adalah fonem [ts]. Penelitian ini dilakukan di kampus Showa, Gunma University kepada 15 orang mahasiswa Indonesia, yang terbagi 2 suku bangsa dengan 2 bahasa daerah yang berbeda (Sunda dan Jawa). Pada penelitian kali ini, pertama-tama, penulis memperdengarkan sebuah rekaman yang berisikan kalimat yang sama dengan teks yang telah dibaca oleh responden, lalu meminta responden untuk mengulanginya dan kemudian merekamnya. Selanjutnya, penulis meminta responden untuk mebaca sebuah teks, kemudian merekamnya kembali. Setelah data terkumpul dan di periksa oleh penutur asli bahasa Jepang, penulis menganalisisnya berdasarkan teori yang ada. Hasilnya menunjukkan bahwa bahasa ibu (bahasa daerah) tidak berpengaruh dalam kealahan pelafalan bahasa dikarenakan responden melakukan kesalahan ditempat yang sama dan persentase jumlah responden yang mampu melafalkan dengan baik dan benar, dengan yang tidak, dapat dikatakan seimbang (50:50). Kemudian, huruf "tsu" yang berada diawal kataatau tidak didahului oleh bunyi apapun lebih rentan terjadi kesalahan. Dengan kata lain, bunyi yang keluar sebelum huruf "tsu" berpengaruh dalam membantu melafalkan fonem [ts] dalam huruf konsonan "tsu".
\end{abstract}

Kata kunci : Fonetik, Huruf Konsonan $T s u$, kesalahan pelafalan, linguistik

Rahmawati Eka Pratiwi : Penulis Utama

${ }^{1}$ Ahmad Dahidi : Penanggung-jawab 1

${ }^{2}$ Nuria Haristiani : Penanggung-jawab 2 


\title{
THE ANALYSIS OF THE PRONOUNCIATION ERRORS "TSU" IN JAPANESE BY THE NATIVE INDONESIAN SPEAKER
}

\author{
Rahmawati Eka Pratiwi, Ahmad Dahidi', Nuria Haristiani ${ }^{2}$ \\ Departemen Pendidikan Bahasa Jepang, Fakultas Pendidikan Bahasa dan Sastra, Universitas \\ Pendidikan Indonesia \\ takagiama@ymail.com
}

\begin{abstract}
At the timen of learning a foreign languange, in general, we would learn the letters of the language. Each language has different phonemes. Learning letters and how to prounounce it is the basis of learning a foreign language learning. Phoneme is the smallest sound that can distinguish the meaning, while the letter is the epitome of sound or phoneme emblem. For example, in the Indonesian language, phoneme /1/ and /r/ differentiates the word "kelas"(class) and "keras" (hard). In relatiom to Japanese languange learning, particulary in writing Japanese loan word, we often find the word of the foreign language written with the same phoneme. For example, the word "light" (cahaya) and "right" (kanan) which have different meanings, but written in the same letters or phoneme symbols /raito/. Such an error will lead to misunderstandings to take place in communication, especially in terms of verbal communication. After comparing of characteristic of phoneme of both Japanese and Indonesia language, it was found out that the phoneme [ts] in the Japanese phonemes does not exitst in the Indonesian language. The research was conducted at the Showa campus of Gunma University involving 15 Indonesian students who were divided into two different ethnicities with two different local languages (Sundanese and Javanese). In her study, the researcher firstly the author played recording of the same sentences as the next text will read later by the respondents. Furthermore, the author asked the respondents to recite it and then record it. Then, the author asked respondents to read a text, and then to record it. again. Once the data were collected and checked by native Japanese speaker, the author analyzed them. The results showed that the local language does not affect the pronouncation errors because the respondents made the misktake at the same place and the percentage of respondents who were able to recite properly, compared to those who were unable to, was equal (50:50). Then, the letters "tsu" located at the beginning of words or not preceded by any sound is more susceptible to errors. In other words, the sound that comes out before the letter "tsu" is influential in helping to pronounce phonemes [ts] in letters "tsu".
\end{abstract}

Keyword : phonetic, Consonant Tsu of Japanese languange, pronounce errors, linguistic 


\section{PENDAHULUAN}

Pada saat mempelajari bahasa asing, pada umumnya kita pun akan mempelajari huruf dari bahasa asing tersebut. Setiap bahasa memiliki fonem yang berbeda-beda. Fonem adalah bunyi terkecil yang dapat membedakan makna, sedangkan huruf adalah lambang bunyi atau lambang fonem. Misalnya, dalam Bahasa Indonesia, yang membedakan kata 'kelas'dan 'keras' adalah fonem /l/ dan fonem /r/.

Dalam contoh lain yang berhubungan dengan bahasa jepang, mari kita bandingkan kata dalam bahasa inggris yang jika di lafalkan dalam bahasa jepang makna nya jadi sulit di bedakan bahkan cenderung sama. Misalnya, kata 'light' (cahaya) dan 'right' (kanan) dalam bahasa inggris memiliki makna yang sama sekali berbeda. Namun, ketika di lafalkan dalam bahasa jepang, keduanya dituliskan dengan huruf (lambang bunyi atau lambang fonem) yang sama, yaitu

「ライト」/raito/. Saat mendengar kata ini dalam kalimat utuh, atau melihat kata ini di dalam sebuah konteks kalimat, secara tidak langsung kita akan faham makna dari kata ini. Namun mudah sekali terjadi kesalah-fahaman makna dalam beberapa kasus. Dalam kasus lain, kata 'this' dalam bahasa inggris misalnya- yang dilafalkan dalam bahasa jepang, biasanya berubah menjadi ' jisu'

「ジス」. Itu dikarenakan, dalam struktur bahasa jepang tidak ada fonem /th/ seperti dalam bahasa inggris dan bahasa jepang mengambil huruf yang paling dekat dengan fonem /th/ yang digabung dengan fonem /i/ tersebut.

Dengan demikian, penulis menggunakan alfabet fonetik internasional (IPA/ International Phonetic Alphabet) untuk membandingkan fonem bahasa indonesia dan fonem bahasa jepang, dan memilah fonem bahasa jepang yang tidak didapati dalam bahasa indonesia

\section{Tabel 1 Fonem Bahasa Jepang yang tidak terdapat dalam Bahasa Indonesia}

\begin{tabular}{|l|l|l|l|}
\hline \multicolumn{2}{|c|}{ 母音(huruf vokal) } & \multicolumn{2}{c|}{ 子音(huruf konsonan) } \\
\hline Fonem & $\begin{array}{c}\text { Contoh kata dalam } \\
\text { Bahasa Jepang }\end{array}$ & Fonem & $\begin{array}{c}\text { Contoh kata } \\
\text { dalam Bahasa } \\
\text { Jepang }\end{array}$ \\
\hline$[\mathrm{w}]$ & うなぎ & {$[\mathrm{c}]$} & ひと \\
\hline$[\mathrm{i}]$ & $\begin{array}{l}\text { よし, } \\
\text { した }\end{array}$ & $\begin{array}{l}\text { した, } \\
\text { しゅご }\end{array}$ \\
\hline & & $\begin{array}{l}{[\mathrm{d} \text { z] }} \\
{[\mathrm{z}]}\end{array}$ & $\begin{array}{l}\text { じぶん, } \\
\text { じょうず }\end{array}$ \\
\hline & & {$[\mathrm{r}]$} & ろく \\
\hline & & {$[\mathrm{ts}]$} & つなみ \\
\hline & & {$[\mathrm{t} 6]$} & $\begin{array}{l}\text { ちかい, } \\
\text { きんちよう }\end{array}$ \\
\hline
\end{tabular}

(https://id.wikipedia.org/wiki/Wikipedia:IPA_untuk_bahasa_Jepang).

Matsuzaki dan Kawano (1998) memaparkan, pembelajar bahasa Jepang selalu lemah dalam beberapa pelafalan. Diantaranya ada perbedaan yang disebabkan oleh bahasa ibu. Dibawah ini akan disebutkan beberapa kesalahan sama yang selalu dilakukan oleh pembelajar bahasa Jepang.

- /u/, yang seharusnya dilafalkan [u] tidak bulat, dilafalkan menjadi bunyi $[\mathrm{u}]$ yang bulat. Contohnya, 「牛」 [u Ji]. 
- / ワ/, dilafalkan menjadi [wa] dengan bunyi yang sangat membulat. Contohnya, 「私」[wata $\int \mathrm{i}$ ].

- Iッ/, dilafalkan menjadi [t Ju] dan [su]. Contohnya, 「机」 [t fukue], 「一つ」 [hitosu].

- Menyampurkan bunyi panjang dan bunyi pendek. Contohnya, 「東京」 [tokjo], 「朝」[a:sa].

- Menggabungkan ada tidaknya bunyi rangkap. Contohnya,「学校」 [gako], 「見た」[mitta].

- Bunyi nasal yang menjadi bunyi [n] dilanjutkan bunyi vokal. Contohnya,

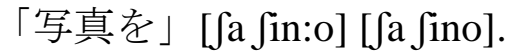

\section{RUMUSAN MASALAH DAN TUJUAN PENELITIAN}

Didalam hasil perbandingan antara struktur bahasa Jepang dan bahasa Indonesia, fonem [ts] merupakan salah satu fonem bahasa Jepang yang tidak dimiliki oleh bahasa Indonesia. Maka dari itu, penelitian ini ingin mencari kesalahan seperti apa saja yang terjadi, dan apa yang menyebabkan kesalahan pada huruf konsonan $\lceil\supset 」$ bahasa Jepang oleh penutur bahasa Indonesia.

Penelitian ini bertujuan untuk mengetahui kesalahan apa saja yang terjadi dalam pelafalan huruf konsonan 'tsu', dan penyebab dari kesalahan pelafalan dari huruf " $t s u$ " pada penutur bahasa Indonesia.

\section{METODE PENELITIAN}

Populasi untuk penelitian ini ada seluruh pembelajar bahasa Jepang. Dan untuk sampel penelitian ini adalah mahasiwa Indonesia yang sedang bersekolah di Gunma University Jepang sebanyak 15 orang. Kelima belas orang ini memiliki level bahasa jepang pemula, dilihat dari kelas bahasa Jepang yang mereka sedang jalani di Gunma University. Penelitian ini di laksanakan dari selama bulan juli hingga september 2015, di kampus showa, gunma university, Jepang.

Pertama-tama, penulis akan membuat beberapa contoh kalimat yang berisikan huruf 「ツ」 dengan berbagai lingkungan, kemudian dibacakan oleh penutur bahasa jepang dan merekamnya. Contoh kalimat ini dibuat dalam 6 jenis. Pertama, menggunakan 「ツ」 yang sebelumnya tidak di dahului oleh huruf lain. Kemudian 「ツ」 dengan didahului oleh bunyi dari huruf vokal「あ」 /a/,「イ」/i/,「う」/u/, 「え」/e/,「お」/o/. Berikut adalah teks yang digunakan sebagai instrumen penelitian.

\begin{tabular}{|l}
\hline 1. つくえのしたに かばんと くつが あります。 \\
2. せんしゅう、 まえばしまつりに いったの? \\
3. めんせつは いつですか。 \\
4. きょう、 おつかれさまでした。 \\
5. つめたいかぜが ふいている。 \\
6. なつといえば あついですね。 \\
7. みずは すこしすつ いれてください。 \\
8. 「ひみつ」という しょうせつは よめば よむほど お \\
もしろくなる。
\end{tabular}




\begin{tabular}{|l}
\hline 9. それは ひとつの りゆうです。 \\
10. そのりょうりは さとうのかわりに、はちみつを つか \\
います。 \\
11. さくらのはなが うつくしいですね。 \\
12. にもつ もちましょうか。 \\
13.あした、せつめいかいが あるらしい。 \\
\hline
\end{tabular}

Seperti yang dibahas sebelumnya, contoh kalimat yang pergunakan adalah 6 jenis. Pertama, huruf 「ツ」 yang tidak di dahului oleh huruf apapun. Kata-kata tersebut antara lain, つくえ、つめたい、つかいます. Kemudian huruf「ツ」 yang sebelumnya didahului oleh huruf vokal「あ」/a/, kata-kata yang dipilih adalah まつり、なつ、あつい.いつ、ひみつ、はちみつ dipilih untuk menjadi contoh kata yang memiliki syarat huruf「ツ」 yang didahului oleh bunyi vokal「い」. Kemudian, huruf 「ツ」 yang didahului oleh bunyi vokal 「う」,kata-kata yang dipilih adalahくつ、ずつ、うつくしい. Untuk huruf「ツ」y yang sebelumnya keluar bunyi vokal「え」penulis memilihkatakata berikut ini，めんせつ、しょうせつ、せつめい. Terakhir, huruf 「ツ」 yang di dahului bunyi vokal「お」dipilihlah kata-kata berikut ini, おつかれ、 ひとつ、にもつ.

Penulis akan mengambil data dengan tes yang dilaksanakan dengan 2 cara, pertama, memperdengarkan rekaman tersebut kepada target penelitian dan meminta target penelitian untuk mengulang apa yang mereka dengar; yang kedua, membacakan teks yang sama dengan suara yang jelas. Kedua tes ini akan di ambil datanya dengan perekam suara dan video. Sebelumnya target penelitian akan di mintai data pribadi nya terlebih dahulu, seperti nama (yang nantinya akan di ganti oleh nomor) dan bahasa ibu (selain bahasa indonesia) untuk mempermudah dalam proses mengklasifikasi dan menganalisis di akhir penelitian.

\section{ANALISIS DATA}

Data yang telah terkumpul di periksa oleh 4 orang penutur asli bahasa jepang. Mereka memeriksa satu per satu pelafalan yang ucapkan oleh orang indonesia yang menjadi sampel penelitian melalui rekaman yang ada, dan menandai bagian-bagian pelafalan yang menurut mereka tidak alami, kemudian menuliskan kembali huruf apa yang terdengar oleh mereka. Setelah itu, penulis hanya memilah data tentang huruf konsonan 「ツ」saja. Penulis memberikan poin kepada setiap kata yang memiliki huruf 「ツ」 didalamnya.

Grafik berikut ini merupakan hasil dari tes membaca. Nilai rata-rata dari hasil tes membaca adalah 3,54. 
Grafik 1 Hasil Tes Membaca

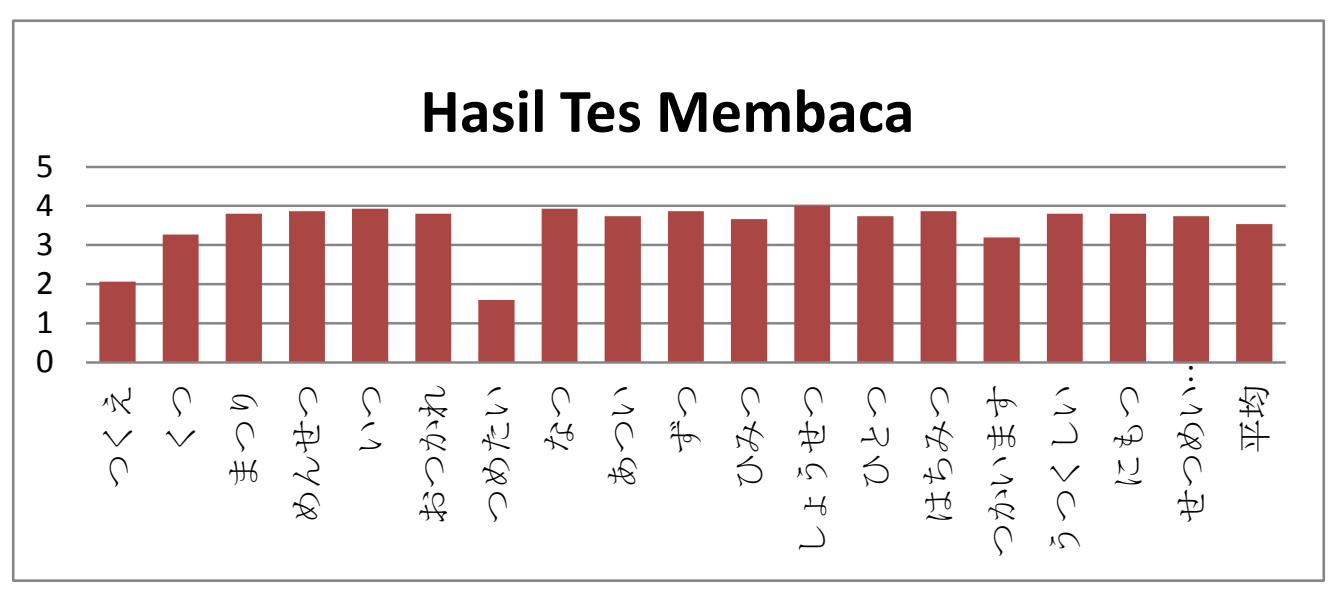

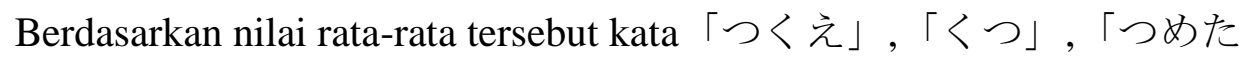
い」dan「つかいます」 menjadi kata yang sering terjadi kesalahan pelafalan $\lceil ツ 」$ didalamnya. Nilai yang didapatkan oleh kata $「 つ く え 」$ adalah 2,07、

「くつ」3,27 poin,「つめたい」 1,6 poin, dan 「つかいます」 mendapatkan nilai 3,2 poin.

Tes mendengar dilakukan dengan cara memperdengarkan rekaman dari native speaker (dengan jenis teks yang sama dengan tes membaca) lalu mengulanginya dan direkam kembali seperti pada tes membaca. Grafik di bawah ini menunjukkan hasil dari tes mendengar. Poin rata-rata dari hasil tes mendengar adalah 3,61 poin.

\section{Grafik 2 Hasil Tes Mendengar}

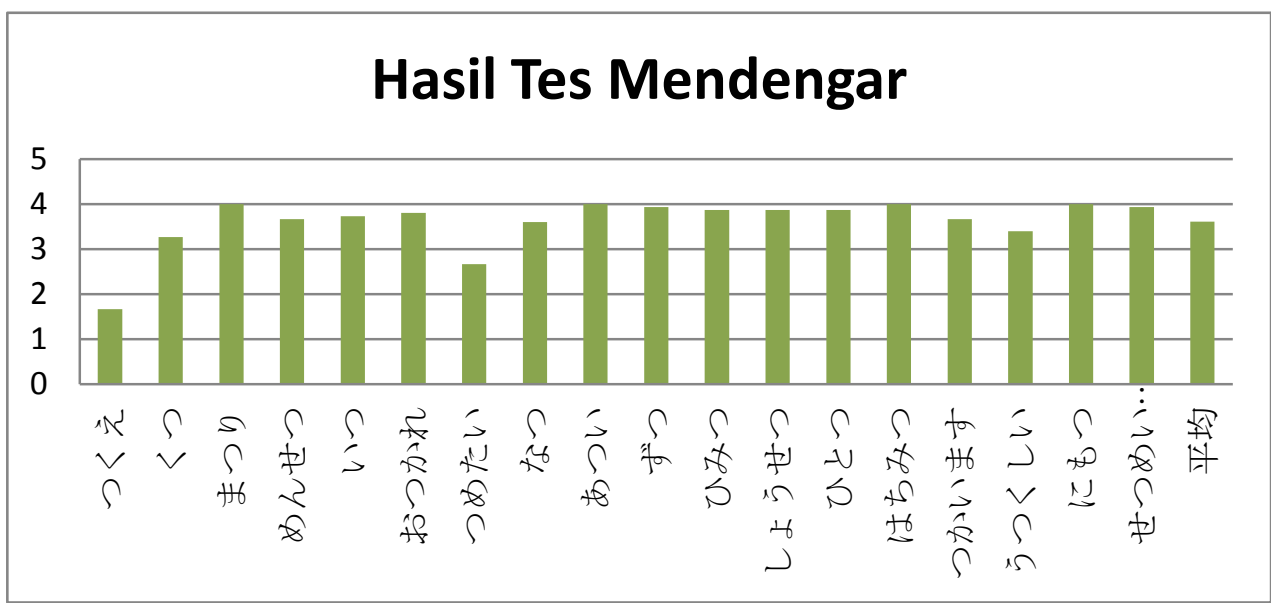

Kata-kata yang memiliki nilai di bawah rata-rata dalam tes mendengar antara lain, 「なつ」 dengan 3,6 poin, 「うつくしい」 dengan 3,4 poin, つ」 dengan 3,27 poin, 「つめたい」 dengan 2,67 poin, dan 「つくえ」dengan 1,67 poin. Beberapa kata dari hasil pada tes ini memiliki kesamaan dengan hasil tes membaca.

Berikut ini adalah hasil dari tes dengan lingkungan suara. Hasil tes dengan lingkungan suara dilihat dari kedua tes, membaca dan mendengar. Hasil menunjukan nilai rata-rata dari tes dengan lingkungan suara pada tes mendeengar ini adalah 3,61 poin. 
Grafik 3 Hasil Tes Mendengar dengan Lingkungan Suara

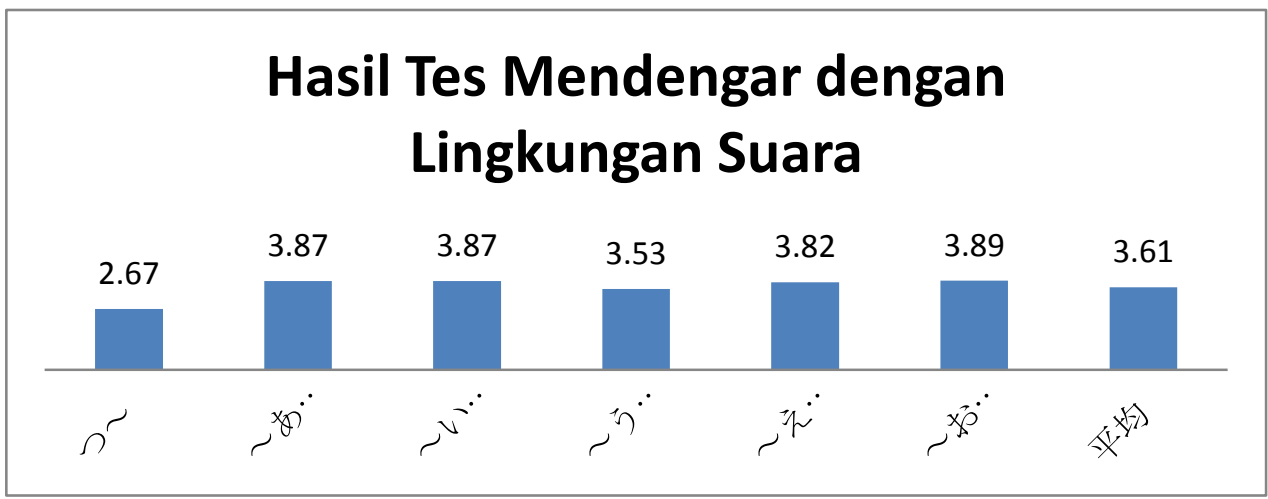

Dalam tes mendengar, kata yang memiliki huruf「ツ」 yang sebelumnya tidak didahuli oleh bunyi vokal apapun, mendapat nilai 2,67 poin dari nilai keseluruhan 4, dan berada cukup jauh dari nilai rata-rata dari hasil tes mendengar dengan lingkungan suara ini, yaitu 3,61 poin. Ini menunjukkan bahwa kondisi lingkungan suara seperti ini sangat mudah terjadi kesalahan dalam melafalkan huruf「ツ」.

Grafik 4 Hasil Tes Membaca dengan Lingkungan Suara

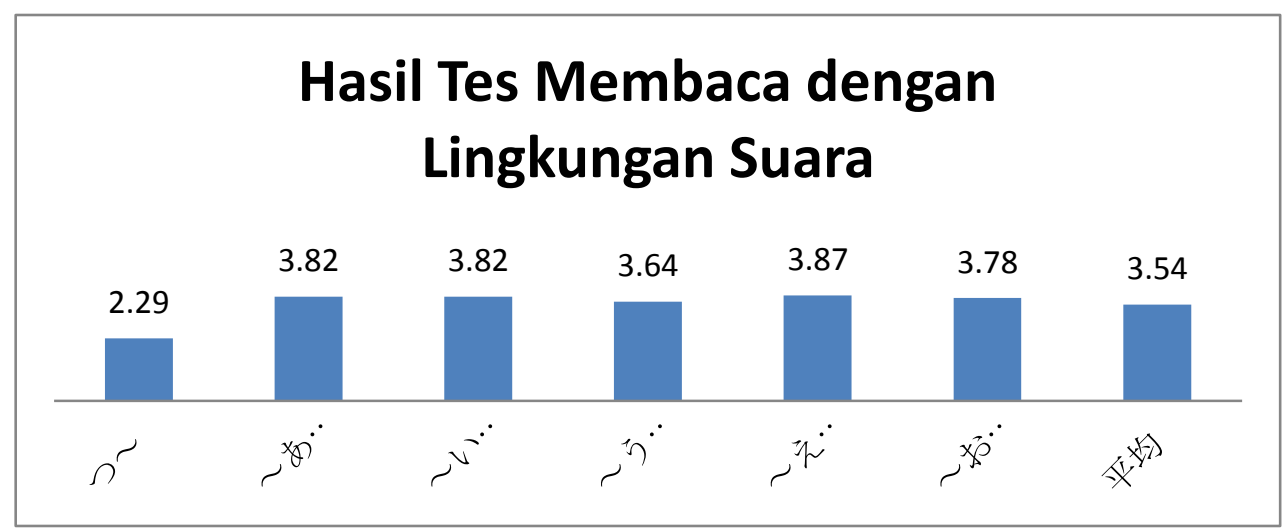

Sama hal nya dengan tes mendengar, dalam tes membaca pun, 「ツ」 yang sebelumnya tidak di dahului oleh bunyi huruf apapun pun mudah sekali terjadi kesalahan pelafan. Grafik menunjukkan angka 2,29 poin untuk jenis lingkungan suara ini.

Tabel 2 Informasi responden dan Persentase tingkat keakuratan pelafalan

\begin{tabular}{|c|l|c|}
\hline No & \multicolumn{1}{|c|}{ Bahasa Ibu (Daerah) } & $\begin{array}{c}\text { Persentase tingkat } \\
\text { keakuratan pelafalan }\end{array}$ \\
\hline 1 & Sunda & $96,5 \%$ \\
\hline 2 & Jawa & $94,5 \%$ \\
\hline 3 & Jawa & $94,4 \%$ \\
\hline 4 & Sunda & $93,8 \%$ \\
\hline 5 & Jawa & $91,7 \%$ \\
\hline 6 & Sunda & $91 \%$ \\
\hline
\end{tabular}




\begin{tabular}{|c|l|l|}
\hline 7 & Sunda & $90,3 \%$ \\
\hline 8 & Sunda & $89,6 \%$ \\
\hline 9 & Sunda & $88,9 \%$ \\
\hline 10 & Jawa & $88,2 \%$ \\
\hline 11 & Sunda & $87,5 \%$ \\
\hline 12 & Sunda & $87,5 \%$ \\
\hline 13 & Sunda & $86,8 \%$ \\
\hline 14 & Jawa & $81,9 \%$ \\
\hline 15 & Jawa & $77,1 \%$ \\
\hline Nilai rata-rata & & $89,3 \%$ \\
\hline Nilai Tertinggi & & $96,5 \%$ \\
\hline Nilai Terendah & & $77,1 \%$ \\
\hline
\end{tabular}

Hasil tes pada tabel diatas diurutkan berdasarkan ranking dari nilai terbesar hingga terkecil serta diambil rata-ratanya. Ranking pertama mendapatkan nilai sebesar 96,5\%, yang merupakan responden berbahasa ibu bahasa Sunda. Sedangkan, nilai terkecil diperoleh oleh responden berbahasa ibu bahasa Jawa, yang mendapatkan nilai sebesar $77,1 \%$. Rata-rata nilai dari semua responden adalah $89,3 \%$. Hasil ini akan digunakan untuk menganalisis apakah bahasa ibu berpengaruh terhadap kesalahan pelafalan ' $t s u$ '.

Karena kesalahan pelafalan huruf 「ツ」/tsu/ yang dilakukan oleh responden terjadi pada tempat yang sama, serta persentase pun menunjukan hasil yang seimbang antara responden yang mampu melafalkan bunyi konsonan "tsu" dengan yang tidak, dapat dikatakan bahwa tidak ada pengaruh dari bahasa ibu (bahasa daerah). Kesalahan ini kembali pada diri pembelajar masing-masing (kojinteki). Namun, pada penelitian kali ini, menulis hanya meneliti dari dua suku (sunda dan jawa) saja, sehingga hasil mungkin akan berbeda jika ditambah dengan suku-suku lain di Indonesia yang memiliki bahasa daerah sendiri.

Hasil dari penelitian ini menunjukan kesalahan pelafalan akan mudah terjadi apabila sebelum huruf konsonan $\lceil つ 」$ tidak muncul bunyi apapun. Dengan kata lain, bunyi yang muncul sebelum huruf $\lceil\supset 」$ cukup berpengaruh dalam membantu untuk melafalkan huruf kosonan $\lceil\supset 」$ dengan benar. Dalam bahasa jepang satu huruf terdiri atas satu silabel (dalam bahasa Indonesia) tidak memiliki satu huruf satu fonem. Maka dari itu pada saat melafalkan bunyi huruf

$\lceil ツ 」$ dalam bahasa jepang, orang Indonesia yang terbiasa dengan satu huruf satu fonem akan mengalami kesulitan saat bertemu dengan dua konsonan satu vokal dalam satu bunyi huruf. Pada waktu melafalkan huruf 「ツ」/tsu/ tanpa ada huruf apapun didepannya rentan terjad kesalahan pelafalan. Namun dalam kasus huruf「ツ」/tsu/ yang terdapat bunyi sebelumnya akan lebih jarang mendapat kendala. Karena ada bunyi(suara) yang mengikat fonem [t] yang ada pada huruf konsonan「ツ」/tsu/ dalam bahasa Jepang. Jika ketika pengucapan huruf「ツ」 tidak didahului huruf konsonan atau vokal, mudah sekali terjadi

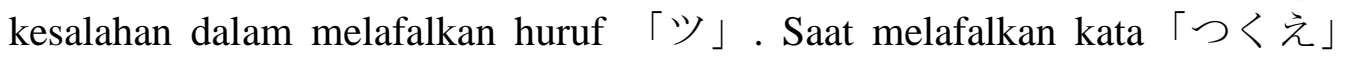

「つめたい」「つかいます」、tidak ada bunyi yang mengikat bunyi fonem 
[t] dalam bunyi huruf 「ツ」 yang merupakan 'hasatsuon' dengan fonem [ts] dan bunyi vokal $[\mathrm{u}]$, yang akhinrnya hanya menyisakan huruf [s] (konsonan frikatif/masatsuon). Maka dari itu, banyak yang melafalkan「ツ」 menjadi 「ス」.

「ツ」 yang merupakan konsonan hambat afrikat (hasatsuon) dan konsonan hambat frikatif「ス」, memiliki titik artikulasi yang sama tapi berbeda dalam menghasilkan bunyi dari cara artikulasinya. Bedanya, konsonan hambat frikatif terjadi ketika pembukaan terhadap suara yang dihasilkan hambatan atau penutupan yang dibuka perlahan, yang melanjutkan bunyi yang dihasilkan dari sebuah hambatan yang tertutup (konsonan hambat/ haretsuon). Maka, kesalahan pelafalan huruf "tsu" yang menjadi "su" itu disebabkan hilangnya bunyi yang dihasilkan dari hambatan yang tertutup (yaitu bunyi konsonan [t]), sehingga hanya ada konsonan frikatif yang mengalir tanpa bertemu dengan hambatan yang tertutup.

Selain berubah menjadi "su", adapun responden yang mengucapkan " $t s u$ " menjadi "chu". "chu" adalah konsonan alveopalatal sedangkan "tsu" merupakan konsonan alveolar. Responden yang cenderung mengucapkan "chu" pada saat akan melafalkan "tsu", terlalu menekan lidah ke atas langit-langit dan ujung lidah yang seharusnya berada diantara gigi dan gusi (pada titik artikulasi huruf konsonan "tsu") tertarik terlalu kebelakang (menjauh dari titik artikulasi yang seharusnya) dan adanya tekanan berlebih.

Dalam tes membaca, responden tidak membaca kalimat secara keseluruhan, namun membacanya kata per kata bukan dalam konteks sebuah kalimat. Jadi, seperti yang telah dibahas sebelumnya mengenai lingkungan suara, pada saat huruf "tsu" berada pada awal kata rentan sekali terjadi kesalahan bunyi atau pelafalan. Maka, dalam kasus kata つかいます yang memiliki nilai rendah dalam tes membaca ini disebabkan kondisi huruf "tsu" yang berada diawal kata atau tidak didahuli bunyi atau huruf apapun terlebih dahulu. Meskipun, jika dilihat dari teks soal, sebelum kata「つかいます」 muncul bunyi huruf vokal

$「 お 」 / \mathrm{o} /$ yang berasal dari partikel 「を」, namun hal tersebut tidak berpengaruh apa-apa dalam tes membaca. Itu dikarenakan, setelah membaca

「を」/o/, semua target penelitian memberi sedikit jeda (ポーズ) sebelum meneruskan kata selanjutnya,「つかいます」.

Sedangkan, dalam tes mendengar, responden mendengar rekaman dari native speaker langsung, sehingga bunyi vokal /o/ yang berasal dari partikel

「を」 yang cukup berpengaruh dalam membantu melafalkan huruf "tsu". Bunyi vokal /o/ mengikat bunyi konsonan hambat dari huruf "tsu" yang dilanjutkan dengan bunyi konsonan frikatif.

Pengetahuan dan pemahaman kosakata dalam bahasa Jepang pun menjadi salah satu hal yang sepertinya berpengaruh dalam melafalkan huruf dalam bahasa Jepang yang baik dan benar. Dapat kita ambil contoh dari kalimat "otsukaresama deshita" dalam tes mendengar, yang mendapatkan angka yang cukup tinggi, 3,8 poin dari keseluruhan nilai 4 poin. Mungkin ini disebabkan responden sering mendengar kata atau ungkapan ini, sehingga tidak ada masalah saat melafalkan huruf konsonan $\lceil\supset 」$ dalam kata atau ungkapan ini. 
Pada saat melafalkan huruf konsonan $\lceil\supset 」$ muncul bunyi bunyi yang dekat dengan bunyi huruf 「つ」. Huruf konsonan 「ツ」/tsu/ merupakan musei shikei hasatsuon, bunyi konsonan hambat frikatif dental alveolar yang tidak bersuara. Bunyi-bunyi yang dekat dengan bunyi huruf konsonan「ツ」 /tsu/ tersebut adalah「ス」/su/, yang merupakan musei shikei masatsuon, dan

「チュ」/chu/ yang merupakan musei shikei kookoogai hasatsuon, serta 'two' (dalam bahasa inggris). 「ツ」dan「チュ」 sama-sama termasuk bunyi konsonan hambat frikatif. 「ツ」 merupakan bunyi konsonan hambart frikatif dental aveolar yang mengeluarkan bunyi dengan menggunakan alat ucap antara gigi dan gusi dengan ujung lidah. Sedangkan, 「チュ」 atau 「チ」 adalah bunyi konsonan hambat frikatif alveolar palatal yang tidak bersuara, yang merupakan bunyi yang dikeluarkan dengan menggunakan alat ucap antara gusi dan langitlangit keras dengan lidah bagian depan.

Terakhir, ini dapat dikatakan merupakan masalah pendengaran. Karena penelitian ini menunjukkan bahwa saat responden melafalkan huruf konsonan " $t s u$ " dengan cara membaca lebih membuat responden berhati-hati dalam melafalkang huruf per huruf nya. Kegiatan mendengarkan memang cenderung lebih sulit dibanding dengan kegiatan membaca. Dalam kegiatan mendengarkan, kita harus fokus pada apa yang kita dengar dan bunyi seperti apa yang akan kita lafalkan. Kesalahan pelafalan yang dilakukan oleh pembelajar pun bisa disebabkan oleh kecepatan berbicara, tinggi-rendahnya, dan atau jelas tidaknya artikulasi dari lawan bicara atau pengajar atau bahkan dari native speaker itu sendiri.

\section{PENUTUP}

Didalam kesalahan pelafalan bunyi $\lceil\supset 」$ dalam bahasa jepang oleh penutur bahasa Indonesia, kesalahan yang terjadi adalah tergantinya bunyi $\lceil つ\rfloor$ oleh bunyi yang dekat dengan bunyi huruf tersebut seperti $「$ ス yang merupakan bunyi konsonan frikatif, bunyi konsonan afrikat「チュ」dan "two" dalam bahasa Inggris. Selain itu, penelitian ini pun menunjukkan bahwa bahasa ibu tidak berpengaruh dalam kesalahan pelafalan $\lceil\supset\rfloor$ dan juga dapat dikatakan bahwa kesalahan pelafalan huruf $\lceil つ 」$ ini merupakan masalah pendengaran (menyimak).

Penulis berharap semoga penelitian ini dapat bermanfaat dalam pendidikan bahasa Jepang, khususnya dalam bidang pembimbingan pelafalan bunyi bahasa Jepang. Dan adapun penelitian mengenai perubahan pelenyapan suara pada bunyi vokal terlalu kompleks dan sulit, maka penulis memutuskan untuk tidak melakukannya dalam penelitian kali ini. Hal-hal yang belum sempat di bahas dalam penelitian kali ini semoga dapat menjadi objek penelitian selanjutnya. Selain itu, penulis pun akan mencari cara melafalkan huruf-huruf bahasa Jepang yang benar, sehingga dapat lebih membantu dalam bimbingan pelafalan huruf bahasa Jepang. 
Pratiwi, Dahidi, Haristiani, The Analysis of The Pronounciation Errors

\section{DAFTAR PUSTAKA}

Hiroshi, Matsuzaki and Kawano Toshiyuki. 1998. Yoku Wakaru Onsei. Tokyo : Space Alc

https://id.wikipedia.org/wiki/Wikipedia:IPA_untuk_bahasa_Jepang 


\title{
インドネシア母語話者における日本語の子音「つ」の発音誤り分析
}

\author{
ラフマワティ・エカ・プラティウィ \\ 1005842
}

\begin{abstract}
要旨
外国語を学ぶ際、対象言語の文字と共に学ばれることが一般的である。言語 によっても音素は異なる。文字の学習とどのような発音をすればいいかとい う事は外国語の学習の基礎である。音素とは意味の相違をもたらす最小の音の単 位であり、文字は音素のシンボルと言える。例えば、インドネシア語の “kelas”

（教室）と“keras”（硬い）という言葉の違いは音素の/1/と/r/である。日本語で は、外国語を書く際に、同じ音素を使う言葉がよくある。例えば、英語の“1ight” と“right”という言葉は同じ音素を使って「ライト」になるのである。このような ことがあるため、コミュニケションの中で誤解が生まれやすいのは当たり前である。 特に、誤解が生まれやすいのは口頭でのコミュニケションの中である。そこで、国 際音声記号を使って、インドネシア語の音素と日本語に音素を比較して、イ ンドネシアにはない日本語の音素を挙げる。 $[\mathrm{ts}]$ という音素はインドネシア 語にない日本語の音素の一つである。本研究では、群馬大学で通うインドネ シア人学生 15 名を対象に、同大学の昭和キャンパスで行った。まず、調査 対象者にその録音を聞いてリピートしてもらいながら録画と録音を取ること にした。その後、調査対象者に文例を読んでもらいながら、録画と録音を取 つた。データが集まってから、日本語母語話者として日本人にデータをチェ ックしてもらい、不自然な発音をしている部分を走査した。不自然な発音か ら聞こえる発音を書きなおしてもらった。チェックが終了した後に分析する。 読む実験と聞き取り実験の結果に基づき、日本語の「つ」の発音が間違って しまうことに、同じところで間違ってしまうため、それに、正用率を見ると、 50\%の対象者が正確に発音できるので、母語の影響はあまりないということ が分かった。それから、前に音がない「つ」の発音は間違いやすいというこ とが分かった。つまり、前にある音は「つ」の正確の発音に影響があるに違 いない。
\end{abstract}

キーワード：音声学、子音の「つ」、発音詋り、言語学 


\section{インドネシア母語話者における日本語の子音「つ」の発 音誤り分析}

\section{1.はじめに}

外国語を学ぶ際、対象言語の文字と共に学ばれることが一般的である。言 語によっても音素が異なる。文字の学習とどのような発音をすればいいか という事は外国語の学習の基礎である。音素とは意味の相違をもたらす最 小の音の単位であり、文字は音素のシンボルと言える。例えば、インドネ シア語の “kelas” (教室) と“keras”（硬い）という言葉の違いは音素 の/1/と/r/である。

日本語には[this] という英語の言葉は「ジス」になることがある。それは なぜかというと、[th］の音素は日本語にはないので、一番近い音を取って 使うことになる。それに、日本語では、外国語を書く際に、同じ音素を使 う言葉がよくある。例えば、英語の“1ight”と“right”という言葉は同 じ音素を使って「ライト」になるのである。このようなことがあるため、 コミュニケションの中で誤解が生まれやすいのは当たり前である。特に、 誤解が生まれやすいのは口頭でのコミュニケションの中である。

そこで、国際音声記号を使って、インドネシア語の音素と日本語の音素を 比較して、インドネシアにはない日本語の音素を挙げる。結果は以下のよ うになる。

表 1 .インドネシア語にない日本語の音素

\begin{tabular}{|c|c|c|c|}
\hline \multicolumn{2}{|c|}{ 母音 } & \multicolumn{2}{|c|}{ 子音 } \\
\hline 音素 & 日本語の文例 & 音素 & 日本語の文例 \\
\hline$[\mathrm{w}]$ & うなぎ & {$[\mathrm{c}]$} & ひと \\
\hline$\left[i_{0}\right]$ & よし, & {$[6]$} & した, \\
& した & & しゅご \\
\hline & & {$[\mathrm{d} z]$} & じぶん, \\
& & {$\left[\mathrm{z}_{\mathrm{g}}\right]$} & じょうず \\
\hline & & {$[\mathrm{r}]$} & ろく \\
\hline & & {$[\mathrm{ts}]$} & つなみ \\
\hline & & & ちかい, \\
& & & きんちょう \\
\hline
\end{tabular}

松崎と河野（1998）では、「ツ」という子音は学習者の苦手な発音の一 つだと言われる。子音の「ツ」は二つの音素で作られ、 $[\mathrm{ts}]$ と [u] の構造で ある。この二つの音素は、インドネシア語のない日本語の音素であるため、 学習者を指導する際には、インドネシア人の日本語の発音の問題を調べて おくことはとても有意義だと思う。 


\section{2 . 研究の問題・目的}

日本語の音韻構造とインドネシア語の音韻構造の結果の中に、［ts］と いう音素はインドネシア語にはないため、本研究では、どのような誤りが 生まれるか、「つ」の間違いやすさの原因は何か、という発音上の問題点 を調査する。

本研究の目的はこの発音誤りの原因と、「つ」の発音の間違いがどのよう な音になるのかを確かめることである。

\section{3. 仮説}

その問題を見ると、仮説は次のようである。インドネシアには民族によっ てインドネシア語だけではなくて、母語として様々な言語がある。そのた め、母語から影響があるかもしれない。それから、「つ」の前にある音か ら影響があると思う。「つ」の音素が二つあるので後ろの音は必ず「う」 の音が出てしまうので、後ろの音は関係がないと思う。そのうえに、この 問題は聞き取るの問題だと思う。なぜかというと、読む際には気を付けて ゆっくり読めるので発音する際にも気を付けることができるので発音が間 違いになる可能性が低いだそうである。

\section{4. 研究方法}

本研究では、群馬大学で通うインドネシア人学生 15 名を対象に、同大学 の昭和キャンパスで行った。その上、対象者がスンダ語話者とジャワ語話 者である。

調査方法では、まず、テスト文例を作り、日本語母語話者として読んでも らい、録音した。テスト文例は以下のようである。

$$
\text { 1.つくえのしたに かばんとくつがあります。 }
$$

2. せんしゅう、まえばしまつりに いったの?

3. めんせつは いつですか。

4.きょう、おつかれさまでした。

5.つめたいかぜが ふいている。

6. なつといえば あついですね。

7. みずはすこしずついれてください。

8.「ひみつ」というしょうせつは よめば よむほど おもしろくな る。

9. それはひとつのりゆうです。

10.そのりょうりは さとうのかわりに、はちみつをつかいます。

11.さくらのはなが うつくしいですね。

12.にもつもちましょうか。

13.あした、せつめいかいが あるらしい。

この文例は 6 種類で作った。最初は、「つ」の前に音が無い言葉である。 それは、つくえ、つめたい、つかいます、という言葉である。そして、

「あ」の音が前にある「つ」である。まつり、なつ、あつい、になった。そ れから、「つ」の前にある「い」の音である。いつ、ひみつ、はちみつ、 
を選んだ。「う」の場合には、くつ、ずつ、うつくしい、である。「え」 の場合には、めんせつ、しょうせつ、せつめい、である。「つ」の前にあ る「お」の音の場合には、おつかれ、ひとつ、にもつ、といら言葉を選ん だ。

次、調査対象者にその録音を聞いてリピートしてもらいながら録画と録音 を取ることにした。その後、調査対象者に文例を読んでもらいながら、録 画と録音を取った。データが集まってから、日本語母語話者として日本人 にデータをチェックしてもらい、不自然な発音をしている部分を走査した。 不自然な発音から聞こえる発音を書きなおしてもらつた。チェックが終了 した後に分析する。

\section{5. データ分析}

収集したデータが 4 人の日本語母語話者にチェックしてもらった。まず、 録音とビデオから対象者としてインドネシア人の発音を一つずつチェック し、日本語母語話者による不自然の発音をマークをし、聞こえる発音を書 きなおしてもらつた。その後、チェックしたデータから日本語の子音の 「つ」だけを走査しておいた。「つ」をついている言葉にポイントを与える ことにした。

ポイントを与える情況はもし 4 人の日本人は全員、ある言葉に「つ」の発 音が正解だと賛成したら、その言葉に 4 ポイントを与える。それから、1人 の日本人が発音が正解だと反対したら、ポイントは 3 ポイントになる。も し、発音が正解だと 2 人の日本人は反対で、 2 人は賛成だとしたら、その 言葉に 2 ポイントを与える。 3 人の日本人がその言葉の「つ」の発音が不正 解だと思ったら、1 ポイントを与える。最後に、この 4 人の日本人がその 言葉の「つ」の発音が不正解だと賛成したら、ポイントは０ ポイントになる。 15 人の対象者のポイントから平均を取ることにした。このようなポイン トの与え方は聞き取りの実験と読む実験のデータにも使用した。

こちらは読む実験のデータチェックの結果である。読む実験の平均は 3, 54 であり、平均に基づいて、「つくえ」、「くつ」、「つめたい」、

「つかいます」という言葉には「つ」の発音がよく間違ったということが 分かってきた。

\section{グラフ 1．読む実験の結果}

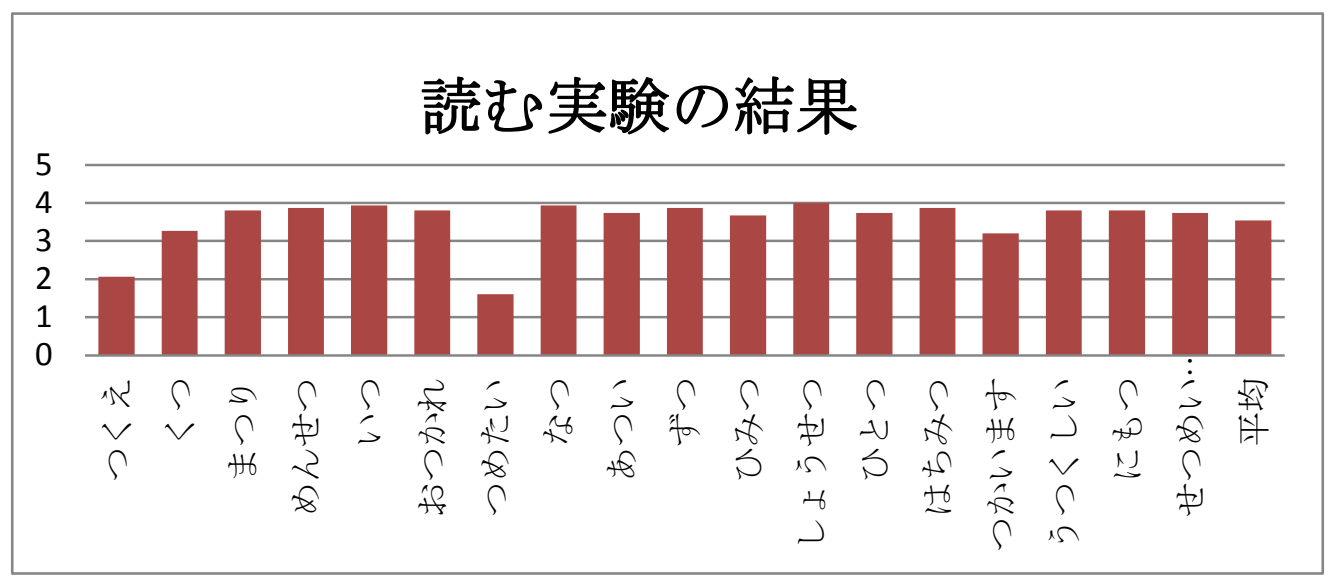


「つくえ」の言葉のポイントは 2,07 で、「くつ」のポイントは 3, 27 であ り、「つめたい」のポイントは 1,6 であり、「つかいます」のポイントは 3, 2 である。

\section{グラフ 2 . 聞き取り実験の結果}

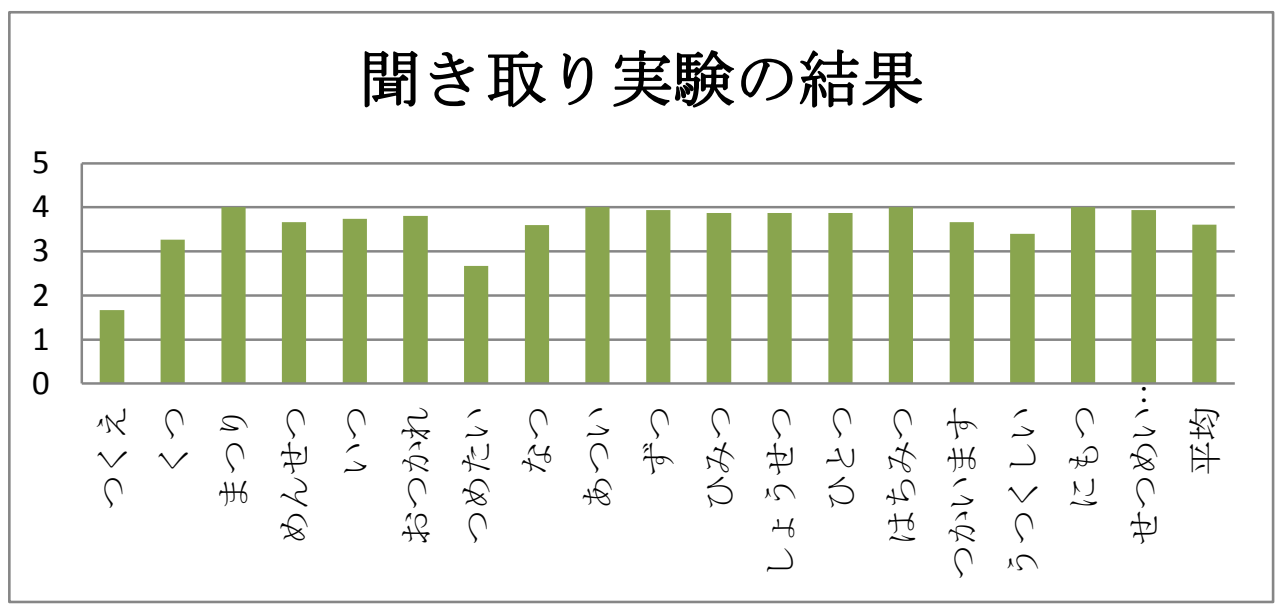

このグラフは聞き取りのテストのデータチェックの結果を示す。聞き取り の結果のポイントの平均は 3,61 である。平均の以下のポイントを走査し、

「つくえ」のポイントは 1,67 で、「くつ」のポイントは 3,27 で、「つめ たい」のポイントは 2,67 で、「なつ」のポイントは 3,6 で、「うつくしい」 のポイントは 3,4 である。

グラフ 3. 環境音の聞き取り実験の結果

\section{環境音の聞き取り実験の結果}

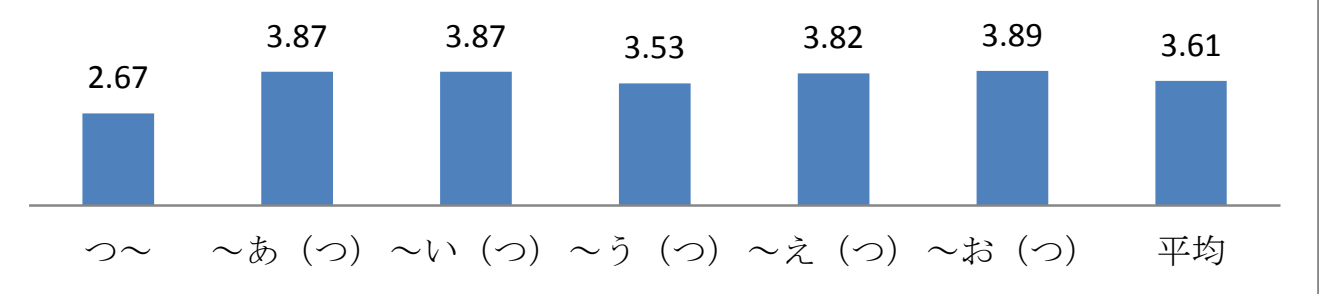

音の環境による結果はこちらである。聞き取りのテストの場合には「つ」 の前に音がないときは満点の 4 ポイントから 2,67 ポイントをもらい、 とても間違いやすいということが分かった。次は、「う」の音が出る「つ」 の文にも結構まちがったときもある。

\section{グラフ 4. 環境音の読む実験の結果}

\section{環境音の読む実験の結果}

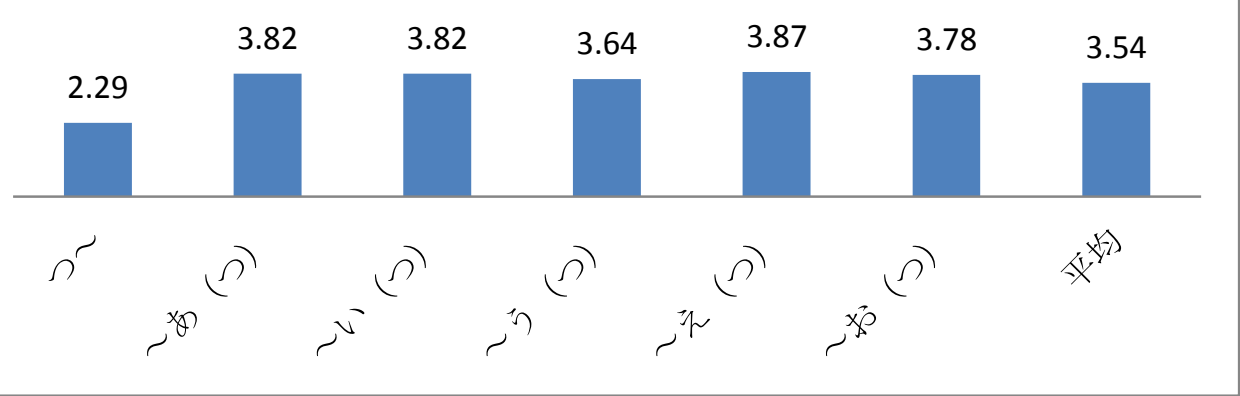


聞き取りのテストのように、読むテストの場合にも前にない音の「つ」間 違ってしまうときは多かった。しかし、読む実験では環境音の「う」が前 にある「つ」のポイントは平均よりもっと高いと示す。

表 2．対象者の情報と実験正用率

\begin{tabular}{|c|l|c|}
\hline 順番 & \multicolumn{1}{|c|}{ 母語 } & 実験正用率 \\
\hline 1 & Sunda & $96,5 \%$ \\
\hline 2 & Jawa & $94,5 \%$ \\
\hline 3 & Jawa & $94,4 \%$ \\
\hline 4 & Sunda & $93,8 \%$ \\
\hline 5 & Jawa & $91,7 \%$ \\
\hline 6 & Sunda & $91 \%$ \\
\hline 7 & Sunda & $90,3 \%$ \\
\hline 8 & Sunda & $89,6 \%$ \\
\hline 9 & Sunda & $88,9 \%$ \\
\hline 10 & Jawa & $88,2 \%$ \\
\hline 11 & Sunda & $87,5 \%$ \\
\hline 12 & Sunda & $87,5 \%$ \\
\hline 13 & Sunda & $86,8 \%$ \\
\hline 14 & Jawa & $81,9 \%$ \\
\hline 15 & Jawa & $77,1 \%$ \\
\hline 平均 & & $89,3 \%$ \\
\hline 最高 & & $96,5 \%$ \\
\hline 最低 & & $77,1 \%$ \\
\hline
\end{tabular}

結果に基づき、母語を問わず、ほとんど同じところで間違ってしまうので、 母語の影響はなさそうだということが分かった。それに、正用率を見ると、 正確に発音できる対象者が、スンダ部族は 9 人から 5 人で、ジャワ部族は 6 人から 3 人だ、ということで別々に $50 \%$ だと表している。

本研究では、部族は 2 つだけ分けて行った。他の部族と対象者の数を加え、 別の効果が出てくるかもしれない。

「つ」の前に母音や子音がなければ、発音が間違いやすいことが分かって きた。つまり、「つ」の前の音が影響を与えるようである。「つくえ」 「つめたい」「つかいます」を発音する際、[ts］の破裂音の［t］を縛る音 はないので摩擦音の [s]だけ残って「す」になってしまうことはよくあった。

「つかいます」という言葉の場合には読むテストの結果と聞き取りの結果 を見ると、違いが表している。聞き取りテストのほうがポイントが高い。 読むテストの際に、対象者の日本語のレベルは低いため、文を読まずに、 言葉を一つずつ読むようになった。「つかいます」の言葉には前に母音の 「お」の音があるが、それはほとんど影響がないと思う。なぜかというと 「を」を読んだ後に、全員がポーズを入れて、「つかいます」を続けた。 
続けた後、他の環境音の「つ」は文頭にする常態のように、発音誤りがよ く起こるようである。対象者の日本語のレベルが上達するにつれて、結果 も変わると思う。

「つ」の発音をするとき、音の環境によっていろいろな「つ」と近い音が 出てきた。例えば、摩擦音の「す」、葉擦音の「ちゅ」、それから英語 の[two］も出てきた。「す」になってしまうことが多かった。

最後、聞き取りのテストと読むテストの結果によると、予想通り、聞き取 りの問題である。聞き取りの活動は相手の発話の速さや声の高低などと繋 がっているらしい。そのため、発音誤りは起こりやすいに違いない。

\section{5.おわりに}

「つ」の発音誤りの中では、どのような音が起きるかと聞くと、「つ」の 一番近い音として、摩擦音の「ス」や破擦音の「チュ」と英語の「two」に なる場合が多かった。その上に、この発音誤りは母語とは関係ないという ことが分かってきた。それに、聞き取り問題とも言える。

日本語教育で、この研究は音声指導に役立てたい。母音の無声化は調査が 複雑になりすぎるので、今回は行わないことにする。こんかい調查できな かったことは今後の課題にしようと思う。発音の正しさもちゃんと調べた いと思う。

\section{参考文献}

松崎寛と河野俊之．1998．『よく分かる音声』。スペースアルク https://id.wikipedia.org/wiki/Wikipedia:IPA_untuk_bahasa_Jepang 